\title{
Where did Braverman go wrong? A Marxist response to the politicist critiques
}

\author{
Onde está errado Braverman? A resposta marxista às críticas politicistas \\ Eduardo Sartelli ${ }^{1}$ \\ Marina Kabat ${ }^{2}$
}

\begin{abstract}
Braverman is considered an unquestionable reference of Marxist labour process. The objective of this paper is to show that despite Braverman's undeniable achievements he forsakes the classical Marxist notions related to work organization, i. e. simple cooperation, manufacture and large-scale industry and replaces them with the notion of Taylorism. We also intend to show that because of this abandonment, Braverman cannot explain properly how the deskilling tendency operates in different historical periods, and in distinct industry branches. Finally, we try to demonstrate that those Marxist concepts neglected by Braverman are especially useful to understand labor unrest related to job organization. Braverman overvalues the incidence of labor fragmentation and direct forms of control and disregards the impact of mechanization achieved with the emergence of Large-scale industry and the new forms of control associated with it. Whereas Braverman's allegedly Marxist orthodoxy is considered responsible for this, in fact, exactly the opposite can be asserted: the weaknesses of the otherwise noteworthy work of Harry Braverman are grounded in his relinquishment of some crucial Marxist concepts. We state that labor processes conventionally considered Taylorist or Fordist can be reconceptualized in Marxist classic terms allowing a better understanding of the dynamic of conflicts regarding labor process.
\end{abstract}

Keywords: Labor process. Politics. Marxism. Regulationism. Workers' Struggles.

\section{Resumo}

Braverman é considerado uma referência inquestionável do processo de trabalho marxista. O objetivo deste artigo é mostrar que, apesar das contribuições inegáveis de Braverman ele abandona as noções marxistas clássicas relacionadas à organização do trabalho, a saber, cooperação simples, manufatura e grande-indústria e substituí-las com a noção do taylorismo. Também pretendemos mostrar que, por causa desse abandono, Braverman não pode explicar adequadamente como a tendência desqualificação opera em diferentes períodos históricos, e em ramos da indústria distintas. Por fim, tentamos demonstrar que esses conceitos marxistas negligenciados por Braverman são especialmente úteis para compreender problemas trabalhistas relacionados com a organização do trabalho. Braverman supervaloriza a incidência de fragmentação do trabalho e formas diretas de controle e desconsidera o impacto da mecanização alcançado com o surgimento da indústria em grande escala e as novas formas de controle associados.

Paper submitted on January $31^{\text {st }}, 2014$ and accepted for publication on August $27^{\text {th }}, 2014$.

DOI: http://dx.doi.org/10.1590/1679-395115865

$1 \mathrm{PhD}$ in Social Sciences, School of Philosophy and Literature, University of Buenos Aires; Academic director of the Center for Studies and Research in Social Sciences (Centro de Estudios en Ciencias Sociales - CEICS); College professor at the Universidad of Buenos Aires - Argentina. Address: Condarco 90, Ciudad Autónoma de Buenos Aires, C1406 AEB, Argentina. E-mail: eduardo.sartelli@yahoo.com.ar

$2 \mathrm{PhD}$ in Social Sciences, School of Philosophy and Literature, University of Buenos Aires; Researcher at the Institute for Research in the Humanities and Social Sciences - National University of La Plata - CONICET (National Council for Scientific and Technological Research); College professor at the Universidad of Buenos Aires and head researcher at the CEICS (Centro de Estudios en Ciencias Sociales - Center for Studies and Research in Social Sciences). Address: Condarco 90, Ciudad Autónoma de Buenos Aires, C1406 AEB, Argentina. E-mail: marinakabat@yahoo.com.ar 
Embora esta responsabilidade seja atribuída à sua alegada ortodoxia marxista, na verdade, exatamente o oposto pode ser afirmado: as fraquezas do trabalho de outra forma notável de Harry Braverman são baseadas em seu abandono de alguns conceitos marxistas cruciais. Afirmamos que os processos de trabalho, considerado convencionalmente taylorista ou fordista pode ser reconceptualizado em termos marxistas clássicos, permitindo uma melhor compreensão da dinâmica de conflitos em matéria de processo de trabalho.

Palavras-chave: Processo de trabalho. Política. Marxismo. Regulacionismo. Lutas Operárias.

\section{Introduction}

The late sixties were witness to a wave of renewed interest in the study of labor processes among Marxists, giving rise to certain new schools of thought. In this context, the work of Harry Braverman (1974) stands out for the detailed and profound unfolding of his research and his strong controversial approach. His work thus inspired the debate which focused mainly on the Marxist discussion over changes in the labor process (SMITH, 1994; LITTLER, 1990; WOOD, 1987). Braverman's achievement was to understand the objective nature of the organization of the labor process and the relation between production process and valorization process and to describe how the deskilling tendency was developing at his time. For those reasons Braverman became an unquestionable reference of Marxist labour process.

The objective of this paper is to show that despite Braverman's undeniable achievements he forsakes the classical Marxist notions related to work organization, i. e. simple cooperation, manufacture and large-scale industry and replaces them with the notion of Taylorism. In our view, this abandonment is related to Braverman's attachment to Baran and Sweezy's theory and has important consequences that we intend to analyze. First, Braverman cannot explain properly how the deskilling tendency operates in different historical periods and in distinct industry branches. In his overvaluation of the incidence of labor fragmentation and direct forms of control he disregards the impact of mechanization achieved with the emergence of Large-scale industry and the new forms of control associated with it. Whereas Braverman's allegedly Marxist orthodoxy is considered responsible for this, in fact, exactly the opposite can be asserted: the weaknesses of the otherwise noteworthy work of Harry Braverman are funded in his relinquishment of some crucial Marxist concepts. We state that labor processes conventionally considered Taylorist or Fordist can be reconceptualized in Marxist classic terms. This leads us to the second consequence: as those Marxist concepts are particularly relevant to comprehend workers response to labor process changes, by discarding them, Braverman - as well as regulationist authors- hinders our understanding of such conflicts.

Strangely enough, Braverman's critics applauded his errors and questioned his truths. As Braverman, most specialists in labor history have underestimated the elucidatory power of the notion large-scale industry not only to comprehend changes in labor processes, but also to understand the evolution of capital itself. On the contrary, they have questioned Braverman's delimitation of his object of study, since, in their judgment it is impossible to study the organization of labor without attending to class struggle. From this point of view, it is indeed the class struggle itself - being the workplace the center of all class disputes- what determines the labor process. Everyone - but Braverman - seemed to agree that the labor process is intrinsically political. At the surface level, the labor rebellion that took place in the '60s and '70s (as the discussion was developing) appeared indeed to confirm this assumption.

It is our thesis that post-Braverman authors have welcomed his errors and rejected his truths, and that, by doing this, they have fallen prey to two fallacies. The first one, the unwarranted idea that the different labor regimes described by Marx (simple cooperation, manufacture and large-scale industry) had been replaced by new systems, which led to the abandonment of those Marxist concepts in contemporary analyses. Until the '70s, some authors concerned with labor process studies still made reference to the concepts of manufacture and Large-scale industry. (BRIGHTON LABOR PROCESS GROUP, 1977; BEECHEY, 1977). But later they seemed to have abandoned the field or modified their theoretical framework. For instance, Touraine published in 1954 his thesis on Renault automotive factory based on those Marxists concepts (TOURAINE, 
1955). Afterwards, he abandons them to the degree of recently quoting and reflecting about that old research, but with a completely different conceptualization (TOURAINE, 1997). Nowadays, the notion of large-scale industry is employed by Marxist authors specialized in economic matters or even in ecology (FOSTER, 1999), but it is often ignored by labor process specialists. One exception among western scholars is the work of Rainnie (1984). Contrary to this, in Latin-America there is a larger group of specialists that continue to develop labor process studies under classic marxists notions (ANTUNES, 1988; PASCUCCI, 2007; BIL, 2007; 2013; SARTELLI, 2001; 2007; SARTELLI and KABAT, 2011a; KABAT, 2008; 2011; FERNÁNDEZ, 1997; HARARI, 2013; CIFARELLI and MARTÍNEZ, 2013; GÓMEZ, n.d.).The second fallacy is the belief that the organization of labor has an intrinsically political nature. In this conception, the factory is seen as a space where workers would have as much initiative as - or even more than - their employers. Actually, it is the first mistake that lays the foundation for the second: those who buried the notion of manufacture could not realize that the manufacture workers were the protagonists of the 70's labor rebellion. In particular, most scholars failed to recognize automobile workers as modern manufacture laborers and, blinded by inaccurate notions, assumed they belonged to the most developed industry branch. Whereas, in fact, in terms of work organization, the automobile industry was behind others which were further mechanized. Ford employees were, mainly, manual workers. Their agitation stemmed from the old and chronic rebellion of the manufacture worker which Marx spoke about. This particular form of labor unrest still arises today in spheres of production where cooperative or manufacture work predominates, while it has been practically extinguished where large-scale industry prevails.

With the development of large-scale industry, workers lose their previous autonomy. The labor process becomes predetermined by the machinery system. Precisely, its design already objectified in machinery allows capital to do away with foremen and the detailed studies of the time and movements in the performance of labor. In other words, all the old manufacture forms of control can simply be eliminated.

Although workers initiatives can eventually affect the organization of labor, class struggle usually tends to either accelerate or delay the mechanization process, but not shape a truly new course for it. They do not affect the labor process in any substantial or lasting way as far as its design and objectives are concerned. It is indeed just the opposite. The labor process actually determines crucial structural aspects of the working class. The development of large-scale industry clusters workers in the modern system of large factories, homogenizes them by destroying all the differences in craftsmanship and modifies family relations with the incorporation of women in labor. The concomitant rise in productivity thus begets the formation of relative surplus population. In short, the labor process imparts to the working class its structural characteristics. Characteristics that Braverman rightly attempted to investigate.

It does not at all imply an economistic point of view to say that the labor process is not immediately political. Political struggle is crucial, but its quintessential space is not the workplace nor is it controlling the capitalist labor relations its main goal. But, as we shall see, those who claim the workplace to be a privileged field for political action tend to reduce it to mere economic conflicts, in detriment of wider struggles and the construction of socialism. ${ }^{3}$

\section{Braverman's Achievements}

Labor and Monopoly Capital is a militant book conceived to intervene in important ideological disputes. On the one hand, it attacks the idea that the demand for skilled workers would perforce increase, by demonstrating the process of de-skilling of the proletariat. It thus defies the idea that there is a tendency

3

In this respect, our analysis is compatible with the standpoint of David Spencer when he avers that an excessively narrow focus on the labor process which disregards the interconnections between workplace organization and capitalist social relations, has often led to an unduly pessimistic political view on the prospects for transcending capitalist domination and has risked to invert the critical intent of Braverman's work by promoting the continuation of the extant social order (SPENCER, 2000). 
towards the enrichment and complexification of labor. On the other hand, it also refutes the view of the working class as divided between blue collar and white collar workers, the latter being regarded as a privileged layer, or even, albeit only in small proportions, as part of the middle class or petty bourgeoisie. This is why Braverman's main concerns are the inter-occupational shifts and the degradation of jobs which were hitherto considered as privileged. He therefore considers 'a working class cadre as it actually exists in the form in which the working class population is molded by capital accumulation' as a priority (BRAVERMAN, 1974, p. 40). This is nothing other than the study of the working class itself, and Braverman knows this opens up a 'third front' against subjectivist interpretations (BRAVERMAN, 1974, p. 41).

Braverman acknowledges the unity of the production and the valorization process. The latter impels all the changes in the labor process. The increase of labor productivity is the aim of all productive changes: the businessman who has bought labor power (and not labor) seeks to obtain the maximum amount of work from it. To that end, this labor power must be controlled. Thus - and this is clearly stated in chapter 1-, such control does not emerge as an end in itself, but a means for further exploitation. However, there are other elements that led Braverman to overrate the problem of control (this will be discussed in further detail below.)

Braverman carries out a critical analysis of a number of censuses to follow the movement of workers employed in the rural and manufacturing sectors going into new activities, such as office and clerical work. He shows how the overcrowding of these activities generated the need to cheapen them; thus giving rise to a new series of transformations in the organization of labor, which - by following the steps formerly developed in the factories- ended up downgrading the working conditions of the new employees to the conditions of the old machine operators. Take for instance office work; once it became large enough, the division of labor ensued, and then it was followed by mechanization.

In order to elucidate the structure of the working class, Braverman also analyzes the conformation of the relative surplus population. He makes a thorough study of the growth of unemployment and he brings into question the official measures, proving that the relative surplus population widely exceeds the official unemployment statistics. This analysis counters the conventional ideas about the end of work or the conceptualization of the unemployed as marginal people. Braverman clearly points out how the relative surplus population is functional to the capitalist system. Again, he makes clear, through a theoretical analysis, that unemployment is a natural consequence of mechanization, and that it is, therefore, a problem inherent to capitalism. In this matter Braverman was ahead of other authors that have recently renewed the studies upon relative surplus population (NEILSON, 2007; 2009; NEILSON and STUBBS, 2011; SEIFFER, KORNBLIHTT and DE LUCA, 2012; KABAT, 2009; 2014).

\section{Braveman's Errors}

Unfortunately, Braverman`s work has some conceptual problems related with his understanding of the historical transformations of the labor process. Braverman demonstrates a deep empirical knowledge of these changes, as evidenced in his descriptions of a large number of industry branches: meat packing plants, furniture, construction, clothing, metallurgy. There's no doubt either about his acquaintance with Marx analysis of the labor process. In a number of passages, he seems to be paraphrasing fragments of The Capital. However, he permanently appears to elude the main concepts conceived by Marx for the study of the labor process -simple cooperation, manufacture and Large-scale industry. For example, in chapter two, a trained reader could infer that he is describing the traits of simple cooperation, but, in fact, that category is never addressed. Instead, Braverman refers to it as "the origin of scientific management". He then describes the backward characteristics of the tailoring industry, which actually correspond to the category of modern manufacture. Yet Braverman does not use that concept either, but replaces it with the notion of 'primitive phase of rationalization'. As a result, Braverman analyzes the contemporary transformations of the labor process as the history of capitalist management, while discarding -without justification- Marxists concepts. 
It is the strong influence that the work of Baran and Sweezy (1968) had on Braverman which motivated the latter to shy away from classical Marxist concepts. We agree with Rowlinson and Hasard that the main errors in Braverman are due to the influence of Baran and Sweezy's work (ROWLINSON and HASARD, 1994). However, we take issue as to what those mistakes are. Further, we believe that the empirical investigation contributed by Braverman can be reconceptualised with Marxist categories and that its main theses, the degradation of labor and the deskilling tendency are valid. In line with Baran and Sweezy, Braverman considers that since the end of the XIX century, capitalism has entered a new stage, the era of monopoly. He then sets out to explain the nature of labor in this new phase. This would be the reason why Braverman tends to conceptualize all these changes as absolute novelties. He also considers some developments as novel when in fact they are not. For example, the association between the piece-rate wage system and the fragmented control of labor had already been noted and explained by Marx: piecework may be applied more amply where labor has already been subdivided because that allows for more exact measurement, which is harder when the worker performs a great variety of operations. So, piece-wage "only conquered a larger field of action during the period of manufacture properly so called". (MARX, 1990, p. 698). Another "novelty" that Braverman attributed to monopoly capitalism is the relation between changes in the labor process and the formation of the world market. However, Marx had already demonstrated that large-scale industry, due to its large production conditions, necessitates the world market and, it therefore revolutionizes transport, thus developing large -scale industry in this sector of the economy too (MARX, 1990, p. 505-506).

Braverman considers that the moments analyzed by Marx under the concepts of manufacture and large-scale industry are early stages already superseded. This is clearly outlined in chapter nine. There, he refers to the appearance of manufacture and its subsequent passage to the regime of large-scale industry as a process already concluded. Manufacture would be the manual labor that precedes the industrial revolution and would thus have implied a change in the organization of labor. Then, with the development of large-scale industry, the instruments of labor change. After this, he states:

To the next question-how is the labor process transformed by the scientific-technical revolution?-no such unitary answer may be given. This is because the scientific and managerial attack upon the labor process over the past century embraces all its aspects: labor power, the instruments of labor, the materials of labor, and the products of labor... (BRAVERMAN, 1974, p. 117).

Braverman naturalizes the idea that the era of monopoly together with the scientific-technical revolution constitutes a new stage to such an extent that he does not devote even a paragraph to prove it. Nor does any other phrase explain why large-scale industry has been superseded. On the other hand, the fact that the elements that he considers typical of this new stage were already present in the previous ones does not seem to attract his attention. The only innovation would be the combination of all these elements. This presumed admixture, however, comes only from Braverman's conceptual mistake.

To understand this better, it is worth mentioning that from a Marxist standpoint to talk about manufacture or large-scale industry as historical stages refers to the period when either of them predominates. In other words, production as a whole may have reached the phase of large-scale industry, yet there might be certain branches in the economy that can still be classed under manufacture or simple cooperation. A good example of a case of study with this perspective is the analysis carried out by Rosa Luxemburg (1977) about the Polish industry. She studies different stages of its devolvement and describes the predominant labour regimes in each of them. The same methodology has been applied to the study of Argentinean industry (PASCUCCI, 2007; BIL, 2007; 2013; SARTELLI, 2001; SARTELLI and KABAT, 2011; KABAT, 2008; FERNÁNDEZ, 1997; HARARI, 2013).

Braverman describes, in certain branches, the passage to manufacture, and in others, the transition towards large-scale industry, but he fails to fully conceptualize each case, by erroneously merging both movements into one single concept: 'scientific management'. As a consequence of this lack of differentiation, the relative importance of these two elements is not recognized; it is, as a matter of fact, subverted. It could be 
said, then, that Braverman overestimates the weight of the division of labor while downplaying the importance of mechanization.

In chapter 3, he explains the effects of the division of labor and the importance of the Babbage principle, and he practically summarizes Marx's characterization of manufacture, though he uses another name for it. However, he does not resume any of the elements that Marx mentions as the limits of manufacture; neither does he explain how the division of labor paves the way for mechanization. Regardless of the nominal issue, what really matters is the fact that he does not conceive a certain kind of division of labor as a historical product with limits begotten by its own development. This is reinforced by the elimination of the concept of large-scale industry. The specific tendencies of manufacture, which Braverman depicts under the name of Taylorism, are transformed into inherent principles of capitalism. He thus states the following: 'The earliest innovative principle of the capitalist mode of production was the manufacturing division of labor, and in one form or another, the division of labor has remained the fundamental principle of industrial organization...'(BRAVERMAN, 1974, p. 49). In turn, concerning the Babbage principle, he says that '...it eventually becomes the underlying force governing all forms of work in capitalistmsociety...' (BRAVERMAN, 1974, p. 81-82), and the most common method of cheapening labor (BRAVERMAN, 1974, p. 82).

Both his empirical research and his theoretical prejudices led Braverman to overestimate the division of labor undervaluing the importance of mechanization and of large-scale industry. The monopolistic conception that he shares with Baran and Sweezy is incompatible with the features and the dynamic characteristic of largescale industry. Marx, based on the analysis of the most advanced branches of his time, conceives large-scale industry as a regime that, under the pressure of competition and with the impetus of science, constantly revolutionizes the labor process.

The monopolistic conception supposes the elimination of competition, and with it, the end of the stimulus for innovation. In fact, Baran and Sweezy (1968) appear to believe that scientific advance and, above all, its applications in the production process, have tended to stagnate. According to this conception, the technical developments and ensuing changes tend to become, at the very least, sluggish. Braverman seems to share this viewpoint: he gives negligible importance to the mode in which machinery revolutionizes the productive forces or to the increase in productivity thus generated. However, he stresses its usefulness for control. Machinery would allow management to obtain the same control as under the Taylorist system but with other means. Braverman, therefore, concentrates only in one of the secondary uses of machinery- control-; and, at the same time, he overlooks the most important one, that is, the breaking up of the subjective basis of the labor process, and its consequent liberation of the productive forces and the increase in productivity.

Even in the chapters about machinery and science, Braverman devotes large passages to the division of labor. He, following Marx, claims that capital seeks to displace labor as the subjective element of the production process. In a footnote, he explains how Marx in the Grundrisse states that this displacement can be fully achieved after a completely automatic set of machines has been developed -which is the same as a fully developed large- scale industry, even though Braverman eludes, once again, this concept. However, he soon forgets Marx's explications in the Grundrisse and declares that the 'reduction of the worker to the level of an instrument in the production process is by no means exclusively associated with machinery' (BRAVERMAN, 1974, p. 119). He argues that the studies of movements and time have allowed for 'treating the workers themselves as machines' (BRAVERMAN, 1974, p. 119). In other words, in his view, scientific management is held responsible for the displacement of the subjective component of the labor process through the objectification of labor. In short, Braverman starts quoting Marx and ends up stating just the opposite to his view: that the objectification of labor is not an exclusive consequence of mechanization, but also a result of the division of manual labor.

In a later article Braverman clearly contradicts himself. On the one hand, he considers the division of tasks as the most important mechanism to cheapen labor power. He points out that "the tendency of the capitalist mode of production from its earliest days some 200 or 250 years ago to the present, when this tendency has 
become a headlong rush, is the incessant breakdown of labor processes into simplified operations taught to workers as tasks" (BRAVERMAN, 1983, p. 53).

He states that this division may arise before the implementation of machinery and refers to the classic example of needle manufacturing described by Adam Smith. On the other hand, he also shows how technology tends to abolish this old division of labor. "Modern technology in fact has a powerful tendency to break down ancient divisions of labor by re-unifying production processes" (BRAVERMAN, 1983, p. 320). If automation tends to abolish the division of labor, which concentrates in the non-mechanized pockets of the economy, Braverman is thinking the wrong way round when he asserts that the division of labor is still the main tendency of capitalism and the principal mechanism to cheapen labor.

Braverman is on the verge of giving the correct answer, but he does not carry through. We consider that his attachment to the theory of monopoly capitalism prevented him from drawing the obvious conclusions: in the branches where maturity has been reached, the labor process does not follow a certain division of labor; instead, all the procedures and steps are constantly revolutionized according to objective criteria, based on the advances of science and technology. The division of labor is the principal mechanism to cheapen labor only in branches that still belong to the manufacture stage: the automobile industry and offices (or those which have just entered commercialization, as it is nowadays the case of the medicines industry in certain countries.) However, mechanization is a much more powerful weapon.

By concentrating his research solely on new branches of the economy, (albeit, with the respectable objective of studying the proletarianization of certain technicians and professionals), Braverman ends up reinforcing his theoretical prejudices. He analyzes the changes in labor among office workers, graphic technicians as well as other similar workers. This also makes his empirical research overvalue the division of labor. His conclusions would have been very different had he concentrated in the early automated textile or milling industries- just to give some examples.

\section{The Marxist Classical Formulation}

Simple cooperation implies the gathering of a greater number of workers to carry out the same task. But in manufacture, labor -in spite of still being manual- is broken up into different operations. Both workers and tools specialize to always perform the same tasks. It is a permanent and lifelong division of labor. Salaries are then determined according to the Babbage principle.

Under manufacture, labor still conserves its subjective character. It is organized following the old handicraft modalities. Its fragmentation reduces the workers' skills individually but not collectively. Its subjective element is neither eliminated nor replaced by a new objective foundation, as will happen in large-scale industry. Since production is still carried out on a subjective basis and the collective laborer has not lost its skills and qualifications yet, the labor process can be reproduced by the workers and their tools. This may occur either individually (i.e. a worker who becomes independent and sets up his own workshop) or collectively, through cooperatives.

Large-scale industry arises from the tendencies of manufacture towards the specialization of work and tools, which are denied by large-scale industry in a dialectical movement. It objectifies labor in an organized system of machines conceived in complete abstraction from the workers skills and the old forms of labor. New material and systems are invented. The division of labor is completely reorganized: processes that had been divided under manufacture may be brought back together again, or there may be processes which undergo new divisions no longer corresponding to the rungs of the old handicraft system.

With the development of large-scale industry the classical manufacture labor division, wage structure and labor control strategies lose their raison d'être. Even when lifelong division of labor could be maintained, it becomes superfluous; in its place, job rotation tends to increase. Equally, while manufacture, with its varied 
range of tasks, each with different requirements (different degrees of specialized knowledge, force, etc.) allows for the operation of the Babbage principle, under large-scale industry, instead, all the skills and qualifications tend to level down at their lowest point. This wage-leveling tendency restricts the utility of the Babbage principle, thus creating a simpler division between the operators of the main machines and their auxiliary workers. Besides, in large -scale industry control is already objectified in the machinery system itself, thus turning unnecessary the manufacture methods of labor control.

Friedman erroneously claims that Marx presupposes a growing development of direct managerial control under capitalism (FRIEDMAN, 1977). His charge is invalid for Marx, but it could be applied to Braverman. By overestimating the historical potentialities of manufacture development, which Braverman calls Taylorism, he is in fact overvaluing the forms of control associated with it. Contrary to this, Marx shows that the forms of control vary in going from manufacture to large-scale industry, and that the latter can dispense with direct control methods. Due to the objectification of control in the machine system, large-scale industry allows multiple forms of management.

The emergence of large-scale industry represents the main transformation in the changes of the labor process. It involves the passage from the formal subsumption to the real subsumption of labor. With largescale industry, it is the labor process itself that constitutes the worker as such. Once a certain technical level is reached, the workers can no longer work on their own. Thenceforth, added to the workers' wage-labor attachment to capital, a much stronger constraint imposes itself: the workers' subjugation to the technical conditions of production. For instance, oil refinery laborers cannot work in this branch by their own means, as could be the case for a carpenter or a shoemaker at the beginning of the 20th century.

Besides, large-scale industry breaks all the earlier barriers to the development of the productive forces emancipating from the craftsmanship's heritage. The technical steps of the productive process are analyzed in abstraction of the workers knowledge or practices and an objective solution is sought through the application of science and technology. Productivity soars and the production time drops.

It is the reduction of production time which proves the amazing breakthrough in the productive forces. Within the productive process, there are moments that are not part of the labor process. All the instances within the productive process where the raw material is not processed by the worker are not part of the labor process. This is why there is a difference between the time required for the completion of the labor process and the production time. Those moments of the production process that are not part of the labor process are, generally, dead cycle stages, i.e. the waiting time when man has nothing to do except wait for the development of some natural process. Some examples of these moments are - among others-the growth of crops or alcohol fermentation. Large-scale industry limits these times and gradually narrows the gap between the production process and the labor process, by reducing the period in which no value is added to the product. This can be clearly observed in the double cropping with hybrid seeds, the shortening of tanning time by using new chemical products, the usage of mechanical moisteners and driers in different industries, or the changes introduced in the production of wine, cheese and other food products as well as in wood drying.

The transition from manufacture to large-scale industry takes the form of modern manufacturing which begins with the incorporation of some machines as isolated elements to the production. As long as a system of machines is not set up, the manufacturing principle is not broken and manual workers can still exert pressure to impose restrictions on the whole system. For instance, by establishing extended and not completely necessary apprenticeships periods or preventing female employment.

Each industry branch develops according to its own pace. Though there is an uneven and combined development that occasionally allows some sectors to skip a specific stage, the new activities are usually, at the beginning, the ones which lag behind. This explains why the automotive industries, in the mid twentieth century, did not reach the phase of large-scale industry that the textile industries had already achieved for quite a while. But, some of the older activities can be delayed due to the nature of the goods they industrialize. The labor process is the result of human labor over nature. There are some natural elements or 
processes which offer greater resistance to the transformation by human labor. This is clearly the case of agrarian production where seasonality is one of the mayor obstacles that should be superseded. In brief, the history of each industry and the nature of the elements which human labor confront are two of the main factors that affect the diverse speed of the transformations of labor process in the different economic branches.

Most of the tertiary sector activities are either new or present different obstacles to mechanization. Consequently, many of them still belong to the manufacture stage, so they employ much more workers than fully mechanized branches. Contrary to other sectors that have completed their passage to large -scale industry, expelling laborers, many third sector activities have not done so, thus absorbing an increasing proportion of the workers employed in the economy. That is the technical basis for the so called tertiarization process.

\section{Marxist Concepts Versus Regulationist Concepts}

In our view, Marxist concepts are more useful to analyze labor process than the regulationist ones (Taylorism, Fordism and Toyotism) due to their greater precision. The Marxist categories are focus on the labor process and are defined by substantial attributes that represent real qualitative differences between one working regime and another. Contrary to this, the regulationist concepts try to condense very diverse elements - such us management, market strategies or the role of the State - being labor just one of them. Although this broad approach may be useful to deal with some problems, it is not accurate enough to understand labor process transformations. Proof of this is the fact that regulationist concepts do not include any definition of the technical basis of labor. For instance they do not indicate even if work is performed by hand or under a mechanized form.

To begin with, Taylorism does not entail a specific technical basis. In strict terms, it is not possible to incorporate Taylorism to a certain stage in the organization of the labor process. Instead, it would seem that its application is feasible, within capitalism, on any technical basis; a fact which Taylor himself was proud of. Therefore, by being compatible with any technical stage of the capitalist development, Taylorism proves to be, in principle, a category of little use when it comes to historicizing labor processes.

However, if we observe where Taylorist practices had a greater real development and analyze their central characteristics, we find that they correspond to manufacturing. Taylorism had wider application in manual work. This, together with the fragmentation of labor and the extensive use of pay scale based on the Babbage principle, constitute typical elements of manufacturing. Taylorism can be understood as the expression of manufacturing trends in its peak of development as well as an ideological current that spread its principles.

The analysis of Taylor's classic, The Principles of Scientific Management, would reinforce our thesis (TAYLOR, 1911). The first principle sustained by Taylor is the need to alienate the workers' skills from the labor process and diminish the importance of the subjective factor in production. These problems, which disappear with large-scale industry, require enormous amounts of energy from capital in the manufacture stage. This explains all the entrepreneurial efforts to control the labor processes that Braverman put so much emphasis on. Through the technical-managerial administration, Taylorism tirelessly attempts to accomplish what the mechanization of the productive process - and even more, its automation- would so easily achieve. For example, Taylor's second principle ascertains the need to remove from the shop floor all the intellectual work and concentrate it on the management of the process, that is, to separate the conception of labor from its execution. Finally, the third principle points to the use of the knowledge of the labor process gathered by management to control each step of the labor process, through the specification of tasks, indicating what should be done, how and when. This becomes unnecessary in automated labor process.

In large-scale industry, the divorce between the conception of labor and its execution has already been consummated. This becomes fundamentally manifest in the role played by science in the configuration of the 
productive process. Similarly, the pace of work and all the operations performed by the workers are governed by the machines and their movements, to which the workers must adapt. In this context, written instructions or any other means of instructing the tasks to be performed would be superfluous; which is especially true if we are dealing with a fully automated machine system.

Management tries to remove the subjective aspects of labor from the control of workers, but this is not the same as eliminating them. Faced with this problem, Taylorism represents once again the most advanced response that manufacture can give: through the study of the movements of the workers it tries to stipulate their tasks, by predetermining the modality and time to complete the job. However, by doing so, Taylorism runs into its own limits. Because, even when all the tasks are specified, and performed as prescribed in all its detail, the subjective element of labor would still not be eliminated: despite the fact that the workers adapt themselves to these conditions, some aspects of the workers are still to be studied, such as their abilities, their working movements and also their physical and psychological wear and tear. Only then is the labor process in conditions of being reorganized, but on the basis of the knowledge that has been gathered about this subjective element. In Marx' words: "The worker has been appropriated by the process; but the process had previously to be adapted to the worker. This subjective principle of the division of labour no longer exists in production by machinery" (MARX, 1990, p. 501).

When the capitalist tries to appropriate the skills of the workers, tearing them into shreds, he does not change the basis of the process. The basis is still craftwork - although it has been broken down. Whereas the individual workers are being deskilled, the collective laborer is not. By contrast, in large-scale industry, the collective worker becomes unskilled and this is not the result of the appropriation of the knowledge of the workers -which has been rendered obsolete by capital- it is rather the outcome of an autonomous development of science.

Marx contrasts the division performed by the worker which is characteristic of manufacture with the analysis of the productive process in it self, which is specific to the regime of large-scale industry, where it is divided into its objective components to be resolved through science. A case in point is the vulcanizing process in the shoe factories during the 20 `s and 30 `s; the different shoe parts, which were formerly stitched, are now glued thanks to the use of new materials, (amongst them rubber,) through a chemical process and an automatic mechanism. The process keeps none of the traits of the previous method. In this case, management did not study the workers, it did not gain control over their knowledge, but it rather independently developed other skills and abilities necessary for the new procedure. The same case applies for a new 'injection' system, implemented 30 years later in the same industry. Here too, there is no such a thing as appropriation of the knowledge of the workers; the process is, instead, continuously revolutionized by means of the development of science and technology (KABAT, 2005).

Fordism is even a less precise notion than Taylorism. On one hand, it is usually associated to a set of factors which are alien to the labor process itself, such as the welfare state or the negotiation through collective labor agreements for wage increases in exchange for higher productivity. None of this, however, is related to the labor process, to what the worker does within production. On the other hand, if we focus on the technical components of the concept we find new problems: Referring to the labor process only, Aglietta defines Fordism as the sum of Taylorism and the assembly line (AGLIETTA, 1988, p. 95-96). It is worth inquiring if the implementation of the assembly line is a completely new element that revolutionizes the basis of the labor process, or if represents a secondary change; in other words, if it is right to mark the beginning of a new phase in the organization of labor based on the introduction of the assembly line. To give another example of a generalized problem, Coriat makes no reference to the manual or mechanized character of labor in defining Fordism. The latter would be about the massive production of standardized products, would share the qualities of Taylorism, but would add two new elements: the system of conveyor belts and the standardization and development of new techniques in assembly (CORIAT, 1980).

First, if we observe the labor process in the branches where the assembly line is incorporated, especially in the paradigmatic automotive industry, we find that work still remains manual. The only mechanized aspect has been the transportation of pieces from one post to another. However, neither the qualifications, nor the 
wage structure or the composition of the working class have been altered by this modification. The workers keep their skills. Given that they differ from one another, it follows that the hierarchy of Babbage's principle can be applied to them. The work has not been simplified to the point of eliminating these differences; it is not that any worker can do any type of task. Thus, Robert Linhart had to try three different posts when he joined the Citroen company in the late 60 `s before being appointed to one where he could meet the minimum production quota. Linhart initially thought that, being a proletarianised student, this was due to his poor manual skills. However, his co-workers told him that the same happened with all new workers (LINHART, 1979). As for any manufacturing work, it is necessary to make a careful selection of the appropriate workers for each specific task. Secondly, the assembly line in itself is not an absolute novelty. It has as its many precedents a series of mechanisms that correspond to typical manufacturing problems such as the isolation of tasks and the need of efficient transport between different sections. In Marx's words:

The establishment and maintenance of a connection between the isolated functions requires that the article be transported from one hand to another and from one process to another. From the standpoint of large-scale industry, this necessity emerges as a characteristic and costly limitation, and one that is immanent in the principle of manufacture (MARX, 1990, p. 463).

If the tasks carried out by most of the workers remain manual, and the assembly line only mechanizes the transport process, then, the automotive industry of the 60s must be appraised as modern manufacture. We consider this concept more appropriate than Fordism since it allows for the enhancement of the central features of work, that is, lack of mechanization. Contrary to this, the notion of 'Fordism' dilutes this trait, to the point that it has been passed over inadvertently by most scholars. Regarding this point, Braverman is more accurate than the Regulationist current: he does not consider Fordism as something radically different; neither does he fail to recognize the manual nature of these types of labor.

Finally, the notion of Toyotism is equally vague. It includes elements which are not part of the labor process, such as 'just in time' management guidelines, employment contract laws and the nature of the relationship between the core firm and its suppliers. Regarding the labor process, this phase would engage automation, the elimination of the assembly line, group work and polyvalence.

As Marx has pointed out, automation is one of the principal tendencies of large-scale industry. This is because, on the one hand, the assembly line is a necessity of modern manufacture; so it follows that, in largescale industry, it is rendered redundant. On the other hand, in large-scale industry, the methods of control are, by and large, objectified in the machine and its automated pace. Therefore, the old system of overseers, as well as other manufacturing forms of control, is no longer peremptory in large-scale industry. On the contrary, large-scale industry is compatible with different forms of labor control, among which is group work. Finally, polivalency or polifunctionality is a tendency of large-scale industry: whereas the manufacturing process required a lifelong specialization of the worker, large-scale industry -by leveling down the qualifications and deskilling the workers- opens the door for polivalence. Thus, the main characteristics of so-called Toyotism, at the level of the labor process, tally with the fundamental tendencies of large-scale industry, especially with its most developed form: automation.

\section{The Manufacture Workers' Rebellion}

The labor conflicts of the 1960's and 1970's can be classed as a manufacturing workers' rebellion. The workers from the non-fully mechanized branches staged different protests against the organization of labor. A typical case is the auto workers who belong to modern manufacture. The characteristics of this labor regime explain the scope of their struggle. They kept a certain margin of workers' control over the labor process, due to the fact that the entire organization of labor still maintained its subjective basis and, at the same time, the control had not been objectified under a system of machinery. 
Despite work fragmentation, while work is not completely mechanized, some qualified jobs still subsist and the workers in charge of them retain a great degree of control. Linhart describes the case of three Hungarian workers who had organized themselves so as to work in turns, two at a time, thus allowing the third one to have a break. They were skilled workers who assembled locks. The workers of the Fiat factory in Argentina are another example: a group of workers, engaged in the quality control of parts, had ample freedom since their boss did not know the time required for the highly skilled tasks which they performed. Eventually, these workers put their knowledge and capabilities at the service of unions' organizations. In Argentina, it was usually the case that the most qualified workers had a very important role in the laborers shop floor organization because they had the technical knowledge needed to discuss work conditions and organization with the managers. Besides, in the context of political upraise, some supervisory personnel took side with the workers. Engineers taught the workers of Fiat how to measure the speed of the conveyor belt, so they could ensure that it wasn't running faster than scheduled (HARARI, 2013).

The above mentioned examples show the weakness of the manufacture regime, which still rests on a subjective basis. To begin with, it is only the individual workers who have been disqualified, not the "collective worker", the workers acting together retain the technical resources needed to fight exploitation in the work place. Secondly, as control has not been objectified, it depends on a large group of foremen, whose loyalty to capital can be undermined. For this reason, businessmen tend to fight against the joint unionization of their blue collars workers and the supervisory staff. In Argentina, in the '50s and '60s this was an important issue, as many unions recruited blue collar workers, clerical employees and managing personnel. The firms asked the government to prohibit this practice alleging that it undermined the factory discipline (KABAT and HARARI, 2013).

However, the manufacture workers' struggle comes forward only within the context of a rising class struggle. It is not a process that occurs 'autonomously' in the factory; it is rather the result of a more general political process in which greater political organizations are at stake. In Argentina, in the ' $60 \mathrm{~s}$, all the struggles related to the labor process took place along with the rise of the so called "classist" or "classconscious" unions and with the conformation of a revolutionary social force that challenged capitalism. This revolutionary social force constitutes an alliance of different fractions of the working class and the radicalized petty bourgeoisie. A similar evolution develops in Europe, in a social context marked by the French May and the Italian "Hot Autumn" events. This is the framework where the strike narrated by Linhart befalls. And he himself, who fostered that movement and was at that time a proletarianised student, who entered the factory with political objectives, is an example of that political alliance. When no political movements of such magnitude take place, scholars tend to magnify workers resistance in everyday struggles. However, these conflicts cannot shape the political horizon of the revolutionary left. One of the examples above mentioned shows the little relevance they have when they are not connected with wider struggles. What the three Hungarians did at work did not escape the notice of the directors of the factory, who tolerated it. In fact, this was even functional for them. The group was only sanctioned after seriously disturbing the company by taking part in the strike described by Linhart (1979).

This is not a phenomenon circumscribed only to the 60's. In Argentina, for example, a first wave of struggles concerning labor process takes places between 1918 and 1921 in the middle of the rise of workers movement and class consciousness (SARTELLI, 2007). National Department of Labor writes a special report on conflicts related to work organization. Almost every economic branch was involved and the workers claims ranged from changes in the disciplinary system and rejection or appeal to the use of certain machines o raw materials to the creation of workers councils. Shoe workers in particular developed important strikes in demand of the elimination of piecework and home-work and claimed for the creation of workers councils. They fulfilled many of their objectives; including even the establishment of workers councils in three different factories. However, the workers` movement - weakened by its internal divisions- is defeated in 1921 when a general strike is ruthlessly suppressed by the government and union leaders are imprisoned. In the ' 20 s, a new advance of mechanization generates more unemployment, thus completely overturning the balance of power in favor of the bourgeoisie. All previous workers conquests were lost in a few years. 
At the second half of the ' 30 s a new cycle initiates. The proletarians fought against the intensification of work demanding the elimination of piecework and better labor conditions. They started to build up internal factory commissions -groups of delegates- that monitor the compliance of labor laws and defend workers' interests in the shop floor. These internal commissions mushroomed in the '40s. During this decade, the workers movement participated in a reformist alliance directed by the bourgeoisie under Perón leadership. On the one hand, this participation of unions in the political alliance that governed the country strengthened labor movement power, but, on the other hand, it tended simultaneously to detract their autonomy and facilitated labor movement regimentation.

As there was no importation of machines at that time, technological changes were then not possible and, therefore, the bourgeoisie could not boost unemployment in order to discipline the labor force. This is another source of the strength shown by the Argentinean workers' movement in mid twentieth century.

During the Peronist Government, unions stipulated progressive work conditions in collective labor agreements. At the same time internal commissions achieved legal recognition and wide prerogatives They interceded in labor disputes and controlled work intensity, supervised the number of workers involved in the different tasks, controlled promotions, and the duties assigned to each worker taking care they were not forced to do any task other than the one they were supposed to. Many times they successfully opposed to labor process changes such as new division of labor, the introduction of homework, or a new wage system that included piecework. (KABAT and HARARI, 2013). Workers' movement and internal commissions outlasted the fall of the Peronist government (1955), and they promoted a resistance to the rationalization programs that began to be implemented. However, - by 1960s- the workers movement was beaten. A series of defeated strikes and a growing unemployment smashed its forces. As we have already explained, it reemerges at the end of the sixties just to suffer a new and deeper downfall in the mid-seventies (SARTELLI, 2007). This shows the "reversibility" of all workers conquests under capitalism, which Anderson (1978) drew attention to. Even what is usually considered the highest form of "workers' control", namely, - the takeover of factories and production - is subject to this reversibility. This is clearly shown by recent Argentinean experience. The Argentinean take-over movement emerged in the political unrest that engendered the 2001 insurrection -known as the Argentinazo- and weakens after the political ebb in 2003. Even in the cases of the successful taken factories that managed to subsist, their debts and commitments, as well as the pressure exerted by the compelling force of the capitalist competition, narrows the freedom of their workers, who are often constrained to self-exploitation (KABAT, 2011b).

\section{The Fallacies of Politicist Criticism}

As noted above Braverman has been challenged for not looking at the workplace as the arena of struggle. For instance, David Montgomery points out that: ' ...far less attention has yet been devoted to the other side of the coin: the workplace as the locale of the workers concerted challenge ...' (MONTGOMERY, 1979, p. 154). Montgomery's writings had a great impact and are considered a touchstone of politicist labor process analysis. He maintains that the labor process organization does not respond to technological determinations but rather to class struggle and that workers constantly develop control initiatives in the shop floor. For instance taylorism would have tried to reply to previous workers wits. ${ }^{4}$ But, according to Montgomery this originated a new resistance movement that even managed to momentarily defeat the 'scientific management movement' in the United States.

For Montgomery, the mainspring of capitalist innovations is to control workers' initiatives instead of increasing surplus value or surviving in the economic competitions. As Sheila Cohen (1987) has remarked

\footnotetext{
4 The same reasoning is used by Holloway regarding "posfordism" labour process which he considerers mainly a bourgeoisie's retaliation to the workers previous fights. Additionally, in an expression of technological determinism, Holloway assumes that these new forms of labor organization would create, by themselves, new resistance movements (HOLLOWAY, 1988).
} 
this control is always defined in rather vague terms and conceals the problem of exploitation. In Montgomery's perspective, the unity of process of production and process of valorization is broken. But his main weakness is his failure to accurately explain what he understands by the notion of workers' control. Through the analysis of the examples that he presents, it can be inferred that he conceives the term in a very broad and fuzzy way, which also includes almost any union demand such as the imposition of working conditions, union recognition and dismissal of the unpopular overseers, regulations of the suspensions or dismissals and solidarity actions.

Montgomery points out three different sources of the workers' control over labor: the autonomy of the craftsman, union regulations and solidarity. He considers that, ultimately, all of them would be based, even symbolically, on the first one. But the workers that Montgomery calls craftsmen belong to a second or third industrial generation. They do not manage the whole craft. They are specialists, such as glassblowers or ironmolders (MONTGOMERY, 1979, p. 144). In Marxists terms, then, they are manufacture workers. According to Montgomery, they would have broad autonomy regarding work execution. However, the tasks are already parceled out. From the very beginning, this parcellation is left outside the 'autonomy' with which the supposed craftsmen 'self-regulated' their own work. Shoe-making partial work, for instance, leaves almost no room for the workers autonomy.

Secondly, Montgomery stresses the autonomy of the craftsmen to manage their own work, but not the lack of it concerning their assistants. In the same manner, even if he provides some examples of the reactionary attitude of the craftsmen by rejecting feminine work, he minimizes it in his idealization of the craftsmen. He believes that the legislation on trade unions divides the positive elements of craftsmen from the negative ones, and that it develops as a continuation of the regulations of craftsmanship. In spite of this, in crucial aspects, the trade unions' regulations represent a break with the craft system, such as for instance, the limitation or prohibition on hiring assistants by the workers. Regardless of the evidence that he himself presents, he does not see the reactionary nature of the craft worker and the need to overcome it so as to give the working class greater homogeneity and unity in action.

Montgomery refers to autonomy even when the work has already been parceled out by the capitalist and fails to understand that piecework pay already implies an external determination regarding the organization of labor. The piece rate payment is established according to the socially necessary labor-time, that is, the average amount of time embodied in a task. So as to have their own subsistence guaranteed, the workers must work at a given pace. Not only that, if that social time supposes a certain division of labor, those who work in their own houses - or those in charge of worker teams- will be compelled to reproduce this division of labor. The study on the division of labor of the work done in family houses shows this thoroughly repeated pattern; this lack of originality is determined by a compulsion external to the worker, crystallized in the piece-rate payment (KABAT, 2014). This coercion forces the workers to go against their own physical integrity, something they would never do if they worked in a truly autonomous way. Piecework pay lures the worker to neglect his personal safety in order to increment his income. This is a reason constantly alleged by unions to prohibit this form of pay (KABAT, 2005; KABAT and HARARI, 2013). This topic has been recurrently reflected in the filmography, see for example, The working class goes to heaven, Germinal and The Perfect Storm (PETRI, 1971; BERRY, 2003; PETERSEN, 2000). In the three films, workers - who are paid by wage-rates- risk their own safety to obtain higher salaries and, in the three cases, this triggers the tragedy over them. The fishermen who wanted to catch more fish get trapped in the storm; the miner who didn't put up beams trying to collect as much coal as possible dies when the mine walls collapses; the metalworker, who unsafely manipulates the machine to make it go faster, loses one of his fingers. None of this can be pondered as an "autonomous" or free will decision. Instead, we consider that this behavior could not be properly understood without the notion of alienation as Marxists authors conceive it (MARX, 2012; LUKACS, 1971; BRAVERMAN, 1974).

Montgomery, who is reluctant to think of work only as space of alienation, ends up idealizing it. For example, he points out that immigrants 'self -regulate' their work pace, specially, by decreasing it at the end of a 12-hour workday. So, mere physical fatigue is presented as a proof of workers 'autonomy'. Furthermore, he conceives job abandonment as one of the most widespread actions taken by workers to exert control over 
their jobs. However, to abandon something is just the opposite of controlling it. Therefore, high turnover rates are usually considered a symptom of labor alienation.

While Montgomery portraits a radical working class, Burawoy attributes a conformist conduct to the contemporary proletariat. Nonetheless their opposition is less outright than it seems. Montgomery and Burawoy both tend to equate workers and capitalist power to shape labor reality, but they have antagonist views regarding the nature of workers behavior. Neither of them understands the factory as the domain of the despotism of capital, but rather as a space open to initiatives from both capitalists and workers. Moreover, these actions within the workplace are studied in abstraction from the social and historical context, so they seem to be rooted in the essential nature of workers. But, neither does the working class always consent exploitation, nor does it contest it permanently. It is no coincidence that the demands for workers' control that Montgomery studies most strongly emerge at the end of 1910 and 1960, in the middle of worldwide revolutionary processes. Conversely, it is not random that Burawoy's thesis over the workers consent is based on a study carried out after the latest defeat of the working class and in the middle of a new bourgeoisie offensive.

A pessimistic, populist and autonomist conception of the working class action is the outcome of these theories. The first critic clearly applies to Burawoy, who thinks that a revolutionary perspective is only possible in peripheral countries; while in central economies, workers' compromise with capitalism obstructs any radical transformation. In contrast, Montgomery believes that the working class is - at all times- ready to fight provided left wing parties do not interfere. Working class actions are considered always accurate. All forms of struggle used by workers are magnified while their eventual sexism, racism and other weaknesses are overlooked. This idealization of the working class reveals a populist view which is complemented by an equally unilateral criticism to left wing organizations. Montgomery holds left organizations responsible for having neglected 'workers' control' issues, while he considers that the State has fostered its development. He traverses a quite paradoxical road then, which begins claiming for workers autonomy and ends up vindicating their integration in the Welfare State. Montgomery also affirms that the IWW (Industrial Workers of the World), by concentrating on the unskilled workers, disdained the tradition of craftsmen autonomy which postponed the problem of workers' control until the post-revolutionary period. In contrast, in the third chapter he concludes that, in the $20^{\text {th }}$ century, the issue of workers' control came to be inextricably intertwined with the State. Naturally, then, this association would have its culminating point in the New Deal. Although he describes the New Deal repressive measures, he states that 'initially it offered significant (though limited) improvements to the workers struggle over the control of the workplace' (MONTGOMERY, 1979, p. 209). Montgomery appears to recognize that labor struggles in themselves cannot guarantee any permanent triumph for the working class. Yet, he still tends to narrow proletariat actions to mere corporative struggles in a horizon of eternal resistance. The end of the alienation of labor does not seem to be a topic in his agenda. Control over capitalist work is the highest goal workers can aim. Ultimately, from this perspective, Montgomery could be considered a pessimist author too. Precisely, as he does not seem to trust in workers' victory, Montgomery recommends minor actions less likely to induce strong reactions. Thus he ponders craftsmen's resistance more effective than trade-union struggles, considering the bourgeois counteroffensive that the latter has provoked in many occasions. 


\section{Conclusions}

Throughout the paper we have shown that Braverman discards the Marxist concepts of manufacture and large-scale industry in his analysis of twentieth century's labor process because he considers them related to earlier periods of capitalism superseded by the advent of the monopolist capital. Scientific management or taylorism would be, in his view, the novel labor process regime that would correspond to this new capitalist phase. However, the elements that he considers typical of this apparent new stage were already present in the previous ones. The only innovation that Braverman points out as a characteristic of this new phase -the combination of elements from the previous stages- is only an impression resulting from a mistaken approach. As industry branches appear in different historical moments and have an uneven development, at any given time of capitalist history there will always coexist diverse labor process regimes.

Braverman believes he is describing a brand new labour regime when he is actually dealing with the passage to manufacture in certain branches and with the transition towards Large-scale industry in others. Indeed, as he concentrates his empirical research in new branches of the economy, with the objective of studying the proletarianization of white collars workers, he tends to focus on the first movement, i. e. in the manufacture development. As a first result, Braverman confuses tendencies specific to the manufacture stage with general laws of capitalism. For instance, he assumes that direct control methods and the Babbage principle are universally applied, while fully fledged Large- scale industry regime is perfectly compatible with a variety of different forms of control and wages structures. As a second consequence, the abandonment of Marxist concepts of manufacture and Large-scale industry thwarts understanding of the struggles related to work organization. The later subjectivist turn in labor process studies worsened this problem and labor organization was to be considered an intrinsically political arena where initiative was held mostly by the workers.

The labor process is not immediately political. Its main determining forces are economic and technical. Economic, due to the unity of the production and valorization process and, therefore, the compulsion generated by competition, which are the principal driving forces to boost labor productivity. Technical: because this higher labor productivity is achieved through the division of labor and mechanization. Workers' struggles can either hinder or accelerate this process as described by Marx in Capital - but they do not alter its basic characteristics.

The labor process has specific political consequences that should be pointed out but not overvalued; namely, the passage to manufacture first and to large-scale industry later gathers all workers in big factories, thus favoring their common action. The development of large-scale industry also helps the homogenization of the workforce, creating the basis for the passage from trade unions to branch unions. Furthermore, the labor process determines the potential shop-floor struggles concerning work control: workers who belong to manufacture still retain certain control over work and have more capacity to combat capital in this field. In fact, the rebellion of the labor force in the 60`s, as we have seen, was led by manufacture workers. Likewise, the present-day cases of labor unrest concerning job organization belong to the manufacture sector too. There has been growing labor unrest and dissatisfaction within the tertiary sector (nurses, teachers, social workers or even computer programmers). They are manufacture workers who express discomfort regarding pressures to increase their productivity and resist to new forms of work division and control that tend to routinize their job causing alienation (CAREY, 2007; 2009; WILKINSON, 2005; STEVENSON, 2007).

However, it shall not be inferred that all struggles related to work organization are only determined by labor process; the broader political context also plays a part: the changing power relation between classes explain most of the specific labor conflicts. While they spread and strengthen when power relations favor the working class, they diminish and weaken in periods of bourgeois reaction. Although labor conflicts, related to workers' control may appear at any time, they tend to accompany the political ebbs and flows of the proletariat, as we have seen in the Argentinean case. 
Those who stress the workers' control potentialities within the current social system tend to ideally embellish the reality of labor by concentrating their studies in the most qualified workers. They place the struggles concerning regulation of the capitalist work in the center of the political arena, thus confining class struggle to the purely economic sphere. Moreover, Large-scale industry workers do not fight for a power they have already lost, neither do so the proletarians transformed into supernumeraries by the large-scale industry. Therefore if political action focuses on labor process disputes, it will necessarily reproduce the current working class fragmentation and will achieve only particular and no lasting victories. The only true way to remove work alienation is collectively, through the abolition of the private ownership of the means of production. In this sense, the current recovery of working class initiatives and the revival of class struggle require new empirical research based on classical Marxist theory, which could, in turn, create knowledge able to support the struggle, no longer for workers' control over capitalist production, but rather for workers' power and the construction of socialism.

Our work has a strong theoretical coincidence with Adler's insight on labor process development; even so, we support a quite dissimilar view of workers' skill trends. This difference has a methodological basis as well as an epistemological one.

On one hand, we accord with him in that Labour process theory (LPT) "has been hobbled by its insufficiently Marxist foundations" (ADLER, 2007, p. 1313) and that LPT ignores the fundamental contradiction Marx saw between the progressive 'socialization' of the labor process and the persistence of capitalist 'valorization' constraints. We also agree that organizational technics can be considered in a twofold manner as means of coercion and as part of the forces of production. In our view, the latter explains why Lenin wanted to develop Taylorism in Revolutonary Rusia. We consider there is still a third facet of these organizational technics, - at least concerning Taylorism, Fordism. That would be their entity as ideological constructions (SARTELLI, 2001).

We also share Adler's critics to the politicism of LPT and his recognition of a technical determination of the labor process. Correspondingly, we also consider that LPT has given too much attention to the struggles related to work intensity. We have contributed to further develop that argument explaining why some economic branches, in specific periods of time, tend to be fertile grounds for claims regarding work organization.

Finally we consider that it is true that the LPT must develop long run studies and not confine itself to case studies guided by a contingent conception of labor process evolution. But, on the other hand, we disagree on the path to tackle that task. Adler uses the term "Paleo Marxism" to refer to his approach built under the precept that a return to the classic texts of Marx will allow a better understanding of the evolution of long run labor processes. Thus, his thesis relies more on a reinterpretation of other studies under the light of Marxist texts - in his words "paleo Marxist lenses" (ADLER, 2007, p. 1329) - than on an empirical research of his own. Based on the United States' census of occupations, Adler asseverates that there is an upgrade tendency instead of a deskilling one. He summarizes some of Braverman's critiques to his methodological approach on the subject but - as we will explain in detail in the following paragraph- he dismisses them on the grounds of Goldin and Katz surveys.

Adler states that Goldin and Katz show that a high-school and college education has continued to yield a sizable positive economic return in the labor market. Adler assumes that if capital rewards college education, it would be because it needs a more educated labor force. However, wage differentials have undergone important variations in the last century. Goldin and Katz themselves interpret the latest elevation in the returns to college educated work force mainly as a consequence of a relative shrinkage in the supply of college educated work force - i. e. a slowdown in the rate of university graduates (GOLDIN and KATZ, 2007, p. 9). The withdrawal of public investments on college education is accounted for the decrease of the rate of high school graduates who entered college for the concomitant relative fall in the offer of college graduated workforce. In such manner, instead of explaining the relative increment in college graduate's wages by the increase of professionals' demand in the labor market - as Adler assumes-, Goldin and Katz attribute it mostly to the relative decline of their offer. Finally, Goldin and Katz find that the higher 
economic return to high School graduates is partially the product of an increasingly dispersed wage structure, originated in the latest working class political recoil and in the dismantling of union's regulations (Goldin and Katz, 1999, 24). This represents an alternative explanation to the one proposed by Adler. In sum, considering both college and high schools graduates, it can be said that Goldin and Katz's survey does not provide such a conclusive evidence for Adler upgrade thesis. Furthermore, Adler's upgrade thesis disregards important evidence both from educational statistics and from working class structure. Adler does not seem to take into account the degradation of the educational system expressed - for example- in the statistics of functional illiteracy or growing unemployment.

Adler finds the increment of the average education level attained by the workforce to be a solid proof of his up-grade thesis. However, official studies on adults' literacy show the opposite. Data collected in 1993 in the United States for the National Adult Literacy Survey (NALS), which included interviews with approximately 26,000 individuals, found that "21-23 percent (40-44 million out of the 191 million) American adults (defined as age 16 or older) at Level 1, were at the lowest literacy level" (NATIONAL INSTITUTE OF LITERACY, 1998, p. 4), while 25 to $28 \%$ of population barely reaches a level 2 of literacy (NATIONAL INSTITUTE OF LITERACY, 1998, p. 1). A person at Level 1 of literacy often cannot locate eligibility from a table of employee benefits, locate intersection on a street map, identify and enter background information on a social security card application or calculate total costs of purchase from an order form (NATIONAL INSTITUTE OF LITERACY, 1998, p. 4). A new survey carried out in 2003, the National Assessment of Adult Literacy showed that $5 \%$ of American adult population is not literate and that $29 \%$ of the population had only basic reading and computing skills (PUGSLEY, 2011, p. 7). It is very hard to reconcile this image with the working class educational skills Adler portrays.

Moreover, capital does not demand any qualification at all from a growing part of the working class, simply because it does not require its labor power. The increment of the relative surplus population is a consequence of labor process changes, especially an outcome of large scale industry and automation. This population is part of the productivity forces, so when capital cannot employ it productively it proves to have become an obstacle to the further development of productive forces. Thus the growing of the relative surplus population is a clear cut example of the contradiction productivity forces and relations de production.

From our perspective, Marxism represents a huge scientific advance that must be known, valued and utilized; but it is not a sanctuary, a safe theoretical comeback after having gone astray in the woods of postmodernism. The only way to grasp contemporary labor process changes is to study them. No magic theoretical lenses could rescue us from post-structuralist confusion if we do not focus on new empirical research.

The problem that remains is how to achieve that goal avoiding at the same time a narrow focus on study cases and an extremely aggregate depiction insufficiently founded. The answer directs us to the core of our methodological proposal that is the study of the branch industry cases. It must to be stressed that this approach not only represents an intermediate level of analysis, but more importantly, it also allows us to comprehend the historical sequence of labor process transformations which consequently, enables us to decipher/ its main tendencies.

As we have contended in this paper, when this standpoint is disregarded those trends cannot be understood. Without the guide of the history of a given branch industry it becomes difficult to rightly determine if a certain organization practice is the product of an advanced stage of labor process' transformations or -on the contrary- a consequence of its embryonic development. As occurred with the automotive industry in the sixties, it is a common mistake to assume that a relatively new economic branch represents necessarily the more advanced stage in labor organization. On the contrary, new branches tend to appear under the form of manufacture or modern manufacture stage and not in the form of large - scale industry. In other words, new activities do not usually represent the more advanced forms of labor organization, but the more backward ones. So they often express less the overall tendencies of capitalism than the characteristics of the first manufacture steps of labor process transformations in new activities. We have advanced the thesis that the new qualified jobs appear in such new branch industries. A clear example could be software design, as a 
manufacture it does not express the truly capitalist tendencies. The latter would only appear when large-scale industry conquers these new fields of economic activities.

Finally, in our view, there is no chance to evaluate labor's skill evolution without taking into account the global labor market's shifts. Although Adler mentions the increment of low skills jobs in underdeveloped countries, he does not ponder it at all. He just assumes that the capital relocation in countries with a lower educated working class is merely a secondary tendency, but no attempt is made in order to measure the impact of this process. Adler does not carry on an inquiry on global workforce's skills development, so, ultimately he derives his conclusions solely from the United States case.

Adler interprets Marx and Engels's assertion that capitalism develops its own gravediggers' under the light of his upgrade thesis. He considers that: "Over the long run, the overall effect is to create a working class that is increasingly educated, cognitively sophisticated, experienced in large-scale collaborative enterprise and thus increasingly capable of successfully taking on the task of radically transforming society and of assuming the leading role in a new form of society" (ADLER, 2007, p. 1328). Although that would be a quite pleasant scenario, it does not seem to be realistic considering the above mentioned illiteracy statistics and the growing relative surplus population. The construction of a new society will have to be undertaken by the world- wide working class molded by capitalism. Clearly, the more educated this class would be at the moment of taking on that goal, the more favorable the perspectives would be to succeed. But, on the basis of what we have argued here socialist should fight against the current degradation of the educational system, rather than relying on capitalist skills trends.

\section{References}

ADLER, P. S. The future of critical management studies: A paleo-Marxist critique of labour process theory. Organization Studies, v. 28, n. 9, p. 1313-1345, 2007.

AGLIETTA, M. Regulation et crises du capitalism. México: Siglo XXI, 1988 (Spanish translation).

ANDERSON, P. Alcances y limitaciones de la acción sindical. In: ANDERSON, P.; MALLET, S. Economía y política en la acción sindical. Córdoba: Cuadernos de Pasado y Presente, v. 40. p. 56-74, 1973.

ANTUNES, R. A. Rebeldia do Trabalho. O confronto operário no ABC paulista: As greves de 1978/80. San Pablo: Editora da UNICAMP, 1988.

BARAN, P. A.; SWEEZY, P. M. Monopoly capital: An essay on the American economic and social order. New York: Monthly Review Press, 1968.

BEECHEY, V. Some notes on female wage labour in capitalist production. Capital \& Class, v. 1, n. 3, p. 45-66, 1977.

BERRY, C. (dir). Germinal., Berri, C., Bodo Scriba and Pierre Grunstein (prod.). Renaud, Depardieu, G., Carmet, j. (interpreters) France. 130 minutes. 1993.

BIL, D. Descalificados. Proceso de trabajo y clase obrera en la rama gráfica (1880-1940). Buenos Aires: Ediciones RyR, 2007.

La industria argentina de maquinaria agrícola (1870-1975): evolución y problemas de su desarrollo. Buenos Aires: Instituto de Investigaciones Gino Germani, 2009. Available at: <http://biblioteca.clacso.edu.ar/gsdl/collect/ar/ar-030/index/assoc/D4148.dir/ji16.pdf >. Access on: 29/01/2014.

BRAVERMAN, H. Labor and monopoly capital. The degradation of work in the twentieth century. New York: Monthly Review Press, 1974. 
[1982].

The degradation of work in the Twentieth century. Monthly Review. Madrid: Editorial Revolución, 1983

BRIGHTON LABOR PROCESS GROUP. The capitalist labor process. Capital and Class, v. 1, n. 1, p. 3-26, 1977.

CAREY, M. White-collar proletariat? Braverman, the deskilling/upskilling of social work and the paradoxical life of the agency care manager. Journal of Social Work, v. 7, n. 1, p. 93-114, 2007.

. It's a Bit Like Being a Robot or Working in a Factory': Does Braverman Help Explain the Experiences of State Social Workers in Britain Since 1971? Organization, v. 16, n. 4, p. 505-527, 2009.

CIFARELLI, V.; MARTÍNEZ, O. Clase obrera y movimiento obrero en Argentina, situación y desafíos. Theomai: estudios sobre sociedad, naturaleza y desarrollo, n. 19, p. 97-117, 2009.

COHEN, S. A labour process to nowhere? New Left Review, n. 165, p. 34-50, 1987.

CORIAT, B. The restructuring of the assembly line: a new economy of time and control, Capital and Class, v. 4, n. 2, p. 34-43, 1980.

DUMÉNIL, G.; LÉVY, D. Production and management: Marx's dual theory of labor. Value and the World Economy Today. Production, Finance and Globalization. London: Palgrave, 2004.

FERNÁNDEZ, F. Cambios en los procesos de trabajo en la industria argentina actual: el caso de la industria automotriz. Documento de Trabajo Programa de Investigación sobre el Movimiento de la Sociedad Argentina, n. 11, 1997. Available at: <http://pimsa.secyt.gov.ar/publicaciones/DT11.pdf>. Access on: 29/01/2014.

FOSTER, J. B. Marx's Theory of Metabolic Rift: Classical Foundations for Environmental Sociology. American Journal of Sociology, v. 105, n. 2, p. 366-405, 1999.

FRIEDMAN, A. Responsible Autonomy versus Direct Control over Labour Process. Capital and Class, v. 1, n. 1, p. 43-57, 1977.

GÓMEZ, T. A. La gestión de la productividad del trabajo en industrias altamente automatizadas: el caso de la industria petrolera en Bolivia. Búsqueda, n. 113, p. 113-135, $2009 . \quad$ Available at <http://promex.iese.umss.edu.bo/uploads/docs/articulo_1277311046.pdf>. Access on: 29/01/2014.

GOLDIN, C.; KATZ, L. The returns to skill across the twentieth century United States. NBER Working Paper, n. 7126, p. 1-47, 1999.

The race between education and technology: the evolution of US educational wage differentials, 1890 to 2005. n. w12984. National Bureau of Economic Research, 2007. 1-40 p.

HARARI, I. Historia de los procesos de trabajo en la industria automotriz argentina entre 1952 y 1976 . Espacios, Caracas, v. 34, n. 2, artigo 15, 2013. Available at: <http://www.revistaespacios.com/a13v34n02/13340215.html>. Access on: 29/01/2014.

Luchas obreras por el proceso de trabajo: el caso de los obreros automotrices argentinos (1959-1976). Trabajo y sociedad, n. 20, p. 175-192, 2013. Available at: <http://www.scielo.org.ar/scielo.php?pid=S1514$68712013000100012 \&$ script=sci_arttext $>$._Access on: 29/01/2014.

HOLlOWAY, J. La rosa roja del Nissan. Cuadernos del Sur, Buenos Aires, n. 7, p. 138-149, 1988.

KABAT, M. Lo que vendrá. Una crítica a Braverman a propósito de Marx y la investigación empírica. Razón y $\begin{array}{llllll}\text { Revolución, } & \mathrm{n} . & 7, & \text { p. } & 23-39, & \text { Available }\end{array}$ <http://www.razonyrevolucion.org/textos/revryr/prodetrab/ryr7Kabat.pdf>. Access on: 29/01/2014. 
. Del taller a la fábrica. Proceso de trabajo, industria y clase obrera en la rama del calzado (Buenos Aires 18701940). Buenos Aires: Ediciones RyR, 2005.

. La industria del calzado: cambios en la organización del trabajo entre 1880 y 1940. Desarrollo económico, v. 47, n. 188 , p. 639-659, 2008

. La sobre población relativa. El aspecto menos conocido de la concepción marxista de la clase obrera. Anuario

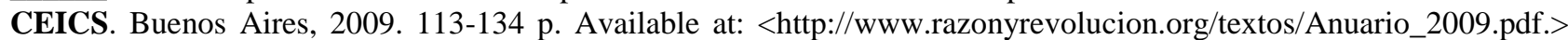
Access on: 18/07/2014.

Los estudios sobre procesos de trabajo: $;$ una respuesta al estancamiento de la historia de los trabajadores?.Anuario de la Escuela de Historia, n. 22, p. 101-123, 2011a. Available at <http://www.revista.ishirconicet.gov.ar/index.php/Anuario/article/view/50/74>._Access on: 29/01/2014.

Argentinean Worker-Taken Factories. In: NESS, I.; AZZELLIN, D. (Eds.). Ours to Master and to Own: Workers' Control from the Commune to the Present, New York: Haymarkert Books, 2011b. 365-381 p.

From Structural Breakage to Political Reintegration of the Working Class: Relative Surplus Population Layers in Argentina and their Involvement in the Piqueter Movement. Capital and Class, v. 38 n. 2, p. 365-384, 2014. Available in: <http://cnc.sagepub.com/content/38/2/365.short>. Access on: 18/07/2014.

; HARARI, I. Los orígenes de las comisiones internas bajo el peronismo. Conflictos en torno a su accionar y reglamentación. In: X JORNADAS DE SOCIOLOGÍA DE LA Facultad de Ciencias Sociales, UBA, Buenos Aires. 2013. CD-ROM.

LINHART, R. De cadenas y de hombres. México: Siglo XXI, 1979 [1978].

LITTLER, C. R. The labour process debate: a theoretical review 1974-1988. Labour process theory, 1990. 46-94 p.

LUKACS, G. History and class consciousness: Studies in Marxist dialectics. Cambridge: The MIT Press, 1971. v. 215.

LUXEMBURG, R. The industrial development of Poland. Campaigner Publications, 1977.

MARX, K. Capital. A critic on political economics. London: Penguin Books, 1990 [1867].

Economic and philosophic manuscripts of 1844. Dover Publications.com, 2012.

MONTGOMERY, D. Workers' Control in America: Studies in the History of Work, Technology, and Labor Struggles. Cambridge: Cambridge University Press, 1979.

NATIONAL InStitute OF LITERACY. The State of Literacy in America: Estimates at the Local, State, and National Levels. Washington U.S. Government Printing Office, 1998.

NEGRI, T. From the mass worker to the social worker, interview regarding workerism. Barcelona: Anagrama, 1980 .

NEILSON, D. Formal and real subordination and the contemporary proletariat: Re-coupling Marxist class theory and labour-process analysis. Capital \& Class, v. 31, n. 1, p. 89-123. 2007.

Sobrepoblación y la teoría marxista de clase. Razón y Revolución, n. 19, p. 15-30, 2009.

; STUBBS, T. Theory and empirical application Relative surplus population and uneven development in the neoliberal era. Capital \& Class, v. 35, n. 3, p. 435-453, 2011.

PASCUCCI, S. Costureras, monjas y anarquistas. Trabajo femenino, iglesia y lucha de clases en la industria del vestido, Buenos Aires, 1890-1940. Buenos Aires: Ediciones RyR, 2006. 
PETERSEN, W. (dir.). The perfect storm. Gail Katz (production), Clooney, G.; Wahlberg, M., Lane, D. Mastrantonio, M. E. Ailen, K. (interpreters). United States. Warner Broos production. 130 minutes, 2000.

PETRI, E. (dir.). The Working Class Goes to Heaven., Volonté, G. M., Melato, M., Pernicé, G. (interpreters). Morricone, E. (music). Italia. Euro International Film. 125 minutes. 1971.

PUGSLEY, R. RP Associates: IALS (International Adult Literacy Survey) its meaning and impact for policy and practice, October 23-25, Banff, Alberta, Canada, Fall Institute, 2011. Available at <http://www.centreforliteracy.qc.ca/sites/default/files/Puglsey_US.pdf>. Access on 20/08/2014.

RAINNIE, A. F. Combined and uneven development in the clothing industry: the effects on competition and accumulation. Capital and Class, v. 8, n. 1, p. 141-156. 1984.

ROWLINSON, M.; HASSARD, J. Economics, Politics, and Labor Process Theory. Capital and Class, v. 18, n. 2, p. 65-97, 1994.

SARTELLI, E. Para comer una Hamburguesa. El estudio de los procesos de trabajo, el debate Braverman y el 'fast food' en Argentina. Razón y Revolución, n. 7, p. 40-61, 2001. Available at: <http://www.razonyrevolucion.org/textos/revryr/prodetrab/ryr7Sartelli.pdf>. Access on: 29/01/2014.

. La plaza es nuestra: el Argentinazo a la luz de la lucha de la clase obrera en la Argentina del siglo XX. Buenos Aires: Ediciones RyR, 2005.

• ¿Cómo se estudia la historia de la industria. Anuario CEICS, n. 1, p. 27-46, 2007.

; KABAT, M. Las transformaciones recientes del proceso de trabajo en el agro argentino y los cambios concomitantes en las relaciones laborales. História na Fronteira, n. 2. p. 43-60, 2011. Available at: <http://www.uniamerica.br/site/revista/index.php/historianafronteira/article/view/80>. Access on: 29/01/2014.

SEIFFER, T.; KORNBLIHTT, J; DE LUCA, R. El gasto social como contención de la población obrera sobrante durante el kirchnerismo y el chavismo (2003-2010). Cuadernos de Trabajo Social, v. 25, n. 1, p. 33-47, 2012. Available at: <http://revistas.ucm.es/index.php/CUTS/article/view/38432>. Access on: 29/01/2014.

SMITH, V. Braverman's Legacy. The Labor Process Tradition at 20. Work and Occupations, v. 21, n. 4, p. 403-421, 1994.

STEVENSON, H. Restructuring teachers' work and trade union responses in England: Bargaining for change? American Educational Research Journal, v. 44, n. 2, p. 224-251, 2007.

TAYLOR, F. W. The principles of scientific management. New York: Harper \& Brothers, 1911.

WILKINSON, G. Workforce remodelling and formal knowledge: The erosion of teachers' professional jurisdiction in English schools. School Leadership and Management, v. 25, n. 5, p. 421-439, 2005.

WOOD, S. The deskilling debate, new technology and work organization. Acta sociologica, v. 30, n. 1, p. 3-24, 1987.

ZEITLIN, J. Social theory and the history of work. Social History, v. 8, n. 3, p. 365-374, 1983. 